\title{
RESPON POLA TANAM JAGUNG-SORGUM TERHADAP BEBERAPA PAKET PEMUPUKAN BERBASIS MIKORIZA INDIGENUS DAN BAHAN ORGANIK DI LAHAN KERING LOMBOK UTARA
}

\author{
Responses of Maize-Sorghum Cropping Pattern to Mycorrhiza-Based \\ Fertilization Packages Applied to Maize on Dryland of North Lombok
}

\author{
Wahyu Astiko *) dan Wayan Wangiyana \\ Program Studi Agroekoteknologi Fakultas Pertanian \\ Universitas Mataram, Jl. Majapahit No. 62 Mataram. Lombok, \\ Nusa Tenggara Barat, Indonesia, 83125 \\ *corresponding author, email: astiko@unram.ac.id
}

Manuscript received: 27-11-2018. Accepted: 08-12-2018

\begin{abstract}
ABSTRAK
Penelitian ini bertujuan untuk mengetahui respon pola tanam jagung-sorgum pada beberapa paket pemupukan ramah lingkungan yang dapat memperbaiki kualitas kesuburan tanah, mengefisiensikan penggunaan pupuk anorganik serta meningkatkan hasil tanaman di lahan kering. Penelitian ini dilakukan di Desa Akar-Akar Kecamatan Bayan Lombok Utara. Rancangan percobaan yang digunakan adalah Rancangan Acak Kelompok, dengan menguji lima paket pemupukan ramah lingkungan pada pola tanam jagung-sorgum dan diulang 4 kali. Hasil penelitian menunjukkan bahwa respon pola tanam jagung - sorgum pada paket pemupukan $60 \%$ lebih rendah dari dosis pupuk rekomendasi dengan penambahan pupuk kandang 12 ton per ha disertai dengan inokulasi mikoriza meningkatkan kesuburan tanah yang tercermin dengan meningkatkan status hara $\mathrm{N}, \mathrm{P}, \mathrm{K}$ dan kandungan bahan organik tanah, meningkatkan serapan hara tanaman ( $, \mathrm{P}, \mathrm{K}$ dan $\mathrm{Ca})$, pertumbuhan, hasil tanaman dan aktivitas MA di dalam tanah.
\end{abstract}

Kata kunci: pola tanam, paket pemupukan, mikoriza, lahan kering

\section{ABSTRACT}

This study aims to determine the response of corn-sorghum cropping patterns on several environmentally friendly fertilization packages that can improve the quality of soil fertility streamline the use of inorganic fertilizers and improve crop yields on dry land. This research was conducted at Akar-Akar Village, Bayan District, North Lombok. The experimental design used was a Randomized Block Design, by testing five environmentally friendly fertilization packages on the corn-sorghum cropping pattern and repeated 4 times. The results showed that the response of maize-sorghum cropping patterns to the fertilizing package $60 \%$ lower than the recommended fertilizer dosage with the addition of 12 tons of manure per ha accompanied by mycorrhizal inoculation increasing soil fertility shown by increasing nutrient status of N, P, K and ingredients soil organic matter, increasing plant nutrient uptake (N, P, K and Ca), growth, crop yields and MA activity in the soil.

Keywords: cropping pattern, fertilizing packages, mycorrhizal, dry land 


\section{PENDAHULUAN}

Ketersediaan $\mathrm{P}$ yang tidak memadai adalah salah satu dari banyak faktor yang membatasi hasil jagung di daerah lahan kering Lombok Utara. Hanya sekitar 8-13\% dari sejumlah pupuk P yang diberikan diserap oleh akar (Supardi, 1996). Salah satu cara untuk memecahkan ketersediaan $\mathrm{P}$ dan unsur hara penting lainnya adalah dengan memanfaatkan mikoriza arbuskular (MA) untuk meningkatkan pertumbuhan dan hasil tanaman.

Inokulasi MA pada tanaman jagung di tanah berpasir sebagai pengganti penambahan pupuk diharapkan memiliki implikasi positif terhadap sifat-sifat tanah, serapan hara dan hasil (Astiko et al, 2013). Penelitian lainnya menunjukkan bahwa tanaman kedelai yang diinokulasi MA dapat meningkatkan serapan $\mathrm{P}$ dan meningkatkan hasil panen dibandingkan dengan yang tanpa inokulasi MA di tanah berpasir (Astiko et al, 2013a). Smith et al. (2010) juga menunjukkan bahwa MA mampu meningkatkan ketersediaan hara dan serapan hara, dan meningkatkan proliferasi akar.

Pola tanam melalui pengaturan urutan jenis tanaman yang berbeda yang ditanam dalam periode setahun dapat menyebabkan berbagai tingkat pengkayaan dalam populasi MA pada siklus tanam berikutnya. Tanaman jagung yang ditanam pada siklus pertama dari pola tanam jagung-kedelai dapat meningkatkan sporulasi MA dan infeksi pada akar tanaman. Ini menyebabkan terjadinya pengkayaan populasi MA di tanah, yang sangat menguntungkan bagi pertumbuhan siklus tanaman berikutnya (Astiko et al, 2013b). Wangiyana et al. (2006) melaporkan dinamika yang berbeda dari populasi MA (kolonisasi MA dan jumlah spora) antara pola tanam pada dua jenis tanah yang dominan di Lombok, Indonesia.

Namun sejauh mana respon pola tanam jagung-sorgum pada beberapa aplikasi paket pemupukan berbasis mikoriza indigenus dan bahan organik terhadap status hara tanah, serapan hara tanaman dan hasil di lahan kering belum banyak diungkap.

\section{METODE PENELITIAN}

\section{Tempat dan desin penelitian}

Penelitian ini dilakukan di Desa Akar-Akar Kecamatan Bayan Lombok Utara. Rancangan percobaan yang digunakan adalah Rancangan Acak Kelompok dengan 4 ulangan. Lima paket pemupukan pada pola tanam jagung-sorgum. yang diuji adalah:

\begin{tabular}{clc}
\hline Pemupukan & \multicolumn{1}{c}{ Siklus tanam pertama } & \multicolumn{1}{c}{ Siklus tanam kedua } \\
\hline $\mathrm{D}_{0}$ & $\begin{array}{l}\text { Jagung }(100 \% \text { dosis rekomendasi pupuk } \\
\text { anorganik NPK })\end{array}$ & Sorgum (tanpa pemupukan) \\
$\mathrm{D}_{1}$ & $\begin{array}{l}\text { Jagung }(80 \% \text { pupuk anorganik }+15 \text { ton } \\
\text { pupuk kandang + mikoriza) }\end{array}$ & Sorgum (tanpa pemupukan) \\
$\mathrm{D}_{2}$ & $\begin{array}{l}\text { Jagung }(60 \% \text { pupuk anorganik }+12 \text { ton } \\
\text { pupuk kandang + mikoriza) }\end{array}$ & Sorgum (tanpa pemupukan) \\
$\mathrm{D}_{3}$ & $\begin{array}{l}\text { Jagung (40\% pupuk anorganik }+9 \text { ton pupuk } \\
\text { kandang + mikoriza) } \\
\text { Jagung (20\% pupuk anorganik }+6 \text { ton pupuk } \\
\text { kandang + mikoriza) }\end{array}$ & Sorgum (tanpa pemupukan) \\
$\mathrm{D}_{4}$ & & Sorgum (tanpa pemupukan) \\
\hline
\end{tabular}

Tanah diolah secara minimum tallage, kemudian dibersihkan dari gulma dan selanjutnya dibuat petak-petak dalam blok berukuran $7 \mathrm{~m}$ x $5 \mathrm{~m}$ sebagai petak perlakuan. 
Inokulasi dengan isolat mikoriza $\mathrm{M}_{\mathrm{AA} 01}$ dilakukan secara cautingseed dengan dosis $1 \mathrm{~kg}$ inokulum per $20 \mathrm{~kg}$ benih. Benih ditanam sebanyak 2 benih pada lubang sedalam 2, setelah berumur 7 hari diperjarang dengan menyisakan 1 tanaman. Untuk penanaman siklus tanam 2, tanah dibersihkan dari sisa-sisa tanaman siklus 1, kemudian digemburkan secukupnya lalu ditanami sorgum. Pengamatan destruksi dilakukan umur 60 hst pada tanaman sampel di masing-masing perlakuan. Benih jagung dan sorgum ditanam dengan jarak tanam $70 \mathrm{~cm}$ x 20 $\mathrm{cm}$. Varietas jagung dan sorgum yang digunakan pada penelitian ini adalah adalah Bisma dan Numbu.

Pemberian pupuk anorganik hanya diberikan untuk tanaman jagung yang ditanam pada siklus tanam 1 sesuai dengan perlakuan. Pemupukan dilakukan dua kali yaitu pada saat tanam dan pada saat tanaman telah berumur 1 bulan. Dosis rekomendasi yang diberikan untuk tanaman jagung adalah $300 \mathrm{~kg} / \mathrm{ha}$ urea dan NPK Ponska (15:15:15) dengan dosis 200 $\mathrm{kg} / \mathrm{ha}$. Pemupukan I dilakukan pada 1 minggu setelah tanam (mst) dengan dosis $100 \mathrm{~kg} / \mathrm{ha}$ dan pupuk NPK Ponska. Pupuk urea ke dua diberikan pada saat 3 mst dengan dosis 200 $\mathrm{kg} / \mathrm{ha}$. Pupuk ditabur sepanjang larikan $5 \mathrm{~cm}$ dari barisan tanaman dengan kedalaman $5-7 \mathrm{~cm}$. kemudian ditutup kembaki dengan tanah. Penyulama tanaman jagung dan sorgum dilakukan setelah 7 hst. Penyiangan dan pembumbunan dilakukan pada saat tanaman berumur $15 \mathrm{hst}$ dan30 hst. Perlindungan tanaman menggunakan pestisida organik OrgaNeem dengan konsentrasi $5 \mathrm{ml}$ per liter air dengan cara disemprot 3 hari sekali.

\section{Analisis bahan tanaman dan kesuburan tanah}

Pemanenan tanaman jagung dan sorgum dilakukan setelah tanaman berumur 100 hst, dengan tanda-tanda biji jagung dan sorgum cukup tua untuk dipanen, yaitu kelobot dan bulir telah berwarna kuning kecoklatan.

Variabel yang diamati adalah variabel kesuburan tanah $(\mathrm{N}, \mathrm{P}, \mathrm{K}, \mathrm{C}$-organik dan $\mathrm{pH}$ tanah) diamati sebelum tanam, umur 60 dan 100 hst. Variabel agronomis meliputi: berat brangkasan kering tajuk dan akar, serapan hara tanaman saat umur 60 hst (N, P, K dan Ca), pertumbuhan dan hasil tanaman (bobot brangkasan kering tajuk dan akar, bobot biji dan 100 biji). Variabel aktivitas MA meliputi populasi mikoriza diamati secara destruktif pada 60 dan 100 hst serta infeksi pada akar dilakukan umur 60 hst.

$\mathrm{N}$ jaringan ditetapkan dengan metode Kjeldhal, $\mathrm{P}$ dengan menggunakan spectrometer, C-organik dengan metode kolorimetri menurut Walkley dan Black, $\mathrm{K}$ dan $\mathrm{Ca}$ dengan menggunakan atomic absorption spectrophotometry (AAS). Variabel populasi mikoriza dilakukan dengan teknik pengayakan basah (wet sieving and decanting) menurut Brundrett et al. (1996). Hasil saringan pada saringan terakhir $(38 \mu \mathrm{m})$ dicuci dengan air mengalir sampai bersih. Supranatan diambil, kemudian ditambah larutan sukrosa 60\% lalu diputar dalam sentrifuge dengan kecepatan $3000 \mathrm{rpm}$ selama 10 menit (Daniel dan Skipper, 1982). Spora yang diperoleh ditaruh dalam cawan Petri untuk dihitung jumlah populasinya per $100 \mathrm{~g}$ tanah di bawah mikroskop stereo dengan pembesaran 40 kali. Penghitungan variabel persentase infeksi dilakukan dengan metode clearing and staining (Kormanik dan Graw, 1982). Persentase infeksi dihitung menggunakan teknik Gridline Intersect (Giovenneti dan Mosse, 1980) di bawah mikroskop stereo. 


\section{Analisis data}

Data hasil pengamatan dianalisis menggunakan analisis sidik ragam (ANOVA), jika terdapat perbedaan yang nyata dilakukan uji lanjut dengan menggunakan Beda Nyata Jujur (BNJ) pada taraf nyata $5 \%$.

\section{HASIL DAN PEMBAHASAN}

Respon pola tanam jagung - sorgum terhadap status hara tanah

Respon pola tanam jagung-sorgum pada perlakuan paket pemupukan $60 \%$ dari dosis pupuk rekomendasi dengan pemberian pupuk kandang 12 ton per ha serta diinokulasi dengan mikoriza $\left(\mathrm{D}_{2}\right)$ memberikan kontribusi positif dan signifikan terhadap peningkatan status hara tanah N, P, K, C-organik dan $\mathrm{pH}$ dibandingkan dengan kontrol $\left(\mathrm{D}_{0}\right)$. Pada pengamatan $60 \mathrm{hst}$ siklus tanam pertama jagung peningkatannya berturut-turut sebesar 18,54\%, 133,93\%, $11,59 \%, 11,57 \%$ dan $1,63 \%$. Sedangkan pada siklus tanam kedua sorgum pengamatan $60 \mathrm{hst}$ meningkat secara nyata terhadap rata-rata status hara $\mathrm{N}, \mathrm{P}, \mathrm{K}, \mathrm{C}$-organik dan $\mathrm{pH}$ berturutturut sebesar 13,63\%, 149,69\%,10\%, 22,72\% dan 4,83\%. Sedangkan pada pengamatan 100 hst siklus pertama jagung peningkatan status hara tanah $\mathrm{N}, \mathrm{P}, \mathrm{K}, \mathrm{C}$-organik dan $\mathrm{pH}$ berturutturut sebesar 39,84\%, 109,75\%, 18,05\%, 11,81\% dan 1,58\%. Sedangkan pada tanaman sorgum siklus kedua pengamatan 100 hst peningkatannya berturut-turut sebesar $20,32 \%$, $195,49 \%, 30,66 \%, 7,93 \%$ dan $7,81 \%$.

Fakta tersebut di atas menunjukkan bahwa aplikasi paket pemupukan $60 \%$ dari dosis pupuk anorganik rekomendasi dengan pemberian pupuk kandang 12 ton per ha serta diinokulasi dengan mikoriza $\left(\mathrm{D}_{2}\right)$ mampu meningkatkan rata-rata status hara tanah baik pada tanaman jagung siklus pertama maupun pada tanaman sorgum siklus tanam kedua. Hal ini mengindikasikan peningkatan status hara tanah dapat dipengaruhi oleh aktivitas mikoriza yang digunakan sebagai pupuk hayati dan cukup efektif dalam meningkatkan status hara tanah pada dosis pupuk anorganik 60\% dari dosis pupuk anorganik rekomendasi dan 12 ton pupuk kandang. Penambahan pupuk anorganik maupun organik (pupuk kandang) sebagai tambahan nutrisi sangat diperlukan untuk meningkatkan efektifitas mikoriza dalam meningkatkan status hara tanah (Astiko et al, 2015).

Tanaman yang bersimbiosis dengan mikoriza merangsang peningkatan panjang akar dibandingkan dengan tanaman yang tidak diinokulasi mikoriza. Pertumbuhan akar yang panjang pada tanaman yang diinokulasi mikoriza akan meningkatkan status hara tanah. Selain itu, adanya hifa eksternal dari mikoriza dapat membantu meningkatkan serapan hara. Miikoriza arbuskular yang menginfeksi sistem perakaran tanaman inang akan memproduksi jalinan hifa eksternal yang dapat tumbuh secara ekspansif, sehingga meningkatkan kapasitas akar dalam penyerapan hara, terutama $\mathrm{P}$ dan $\mathrm{N}$ (Cruz et al., 2004). Rifan et al. (2002) menyatakan bahwa pemberian mikoriza dapat meningkatkan KTK tanah, P tersedia, $\mathrm{N}$ total tanah, serapan $\mathrm{P}$, pertumbuhan tanaman, jumlah polong bernas dan bobot biji per tanaman kedelai. 
Tabel 1. Respon pola tanam jagung - sorgum terhadap status hara tanah (N, P, dan K) serta Corganik dan $\mathrm{pH}$ tanah pada beberapa aplikasi paket pemupukan pada 60 dan 100 hst di lahan kering

\begin{tabular}{|c|c|c|c|c|c|c|c|c|c|c|}
\hline \multirow[t]{2}{*}{ Pemupukan** } & \multicolumn{2}{|c|}{$\begin{array}{c}\mathrm{N} \\
\left(\mathrm{g} \mathrm{kg}^{-1}\right)\end{array}$} & \multicolumn{2}{|c|}{$\begin{array}{c}\mathrm{P} \\
\left(\mathrm{mg} \mathrm{kg}^{-1}\right)\end{array}$} & \multicolumn{2}{|c|}{$\begin{array}{c}\mathrm{K} \\
(\mathrm{cmol} \mathrm{kg}-1)\end{array}$} & \multicolumn{2}{|c|}{$\begin{array}{c}\text { C-org } \\
\left(\mathrm{g} \mathrm{kg}^{-1}\right)\end{array}$} & \multicolumn{2}{|c|}{$\mathrm{pH}^{*}$} \\
\hline & $1^{\mathrm{ma}}$ & $2^{\text {ua }}$ & $1^{\mathrm{ma}}$ & $2^{\text {ua }}$ & $1^{\mathrm{ma}}$ & $2^{\text {ua }}$ & $1^{\mathrm{ma}}$ & $2^{\text {ua }}$ & $1^{\mathrm{ma}}$ & $2^{\text {ua }}$ \\
\hline \multicolumn{11}{|l|}{$60 H S T$} \\
\hline $\mathrm{D}_{0}$ & $1,24^{\mathrm{c}}$ & $1,10^{\mathrm{c}}$ & $14,97^{\mathrm{d}}$ & $\underset{\mathrm{d}}{11,41}$ & $0,69^{d}$ & $0,90^{\mathrm{b}}$ & $12,1^{\mathrm{c}}$ & $11,0^{\mathrm{d}}$ & $6,10^{\mathrm{b}}$ & $\underset{\mathrm{d}}{6,20}$ \\
\hline $\mathrm{D}_{1}$ & $1,45^{\mathrm{a}}$ & $1,29^{\mathrm{a}}$ & $28,44^{\mathrm{b}}$ & $16,25^{\mathrm{b}}$ & $0,74^{\mathrm{b}}$ & $0,98^{\mathrm{a}}$ & $13,3^{\mathrm{a}}$ & $13,1^{\mathrm{b}}$ & $6,10^{\mathrm{b}}$ & $\underset{c}{6,30}$ \\
\hline $\mathrm{D}_{2}$ & $1,47^{\mathrm{a}}$ & $1,25^{\mathrm{ab}}$ & $35,02^{\mathrm{a}}$ & $\underset{\mathrm{a}}{28,49}$ & $0,77^{\mathrm{a}}$ & $0,99^{\mathrm{a}}$ & $13,5^{\mathrm{a}}$ & $13,5^{\mathrm{a}}$ & $6,20^{\mathrm{a}}$ & $\underset{\mathrm{a}}{6,50}$ \\
\hline$D_{3}$ & $1,39^{\mathrm{b}}$ & $1,22^{\mathrm{ab}}$ & $17,52^{\mathrm{c}}$ & $\underset{c}{14,59^{b}}$ & $0,72^{\mathrm{c}}$ & $0,85^{\mathrm{c}}$ & $12,7^{\mathrm{b}}$ & $12,8^{\mathrm{bc}}$ & $6,10^{\mathrm{b}}$ & $\underset{b}{6,40}$ \\
\hline $\mathrm{D}_{4}$ & $1,33^{\mathrm{b}}$ & $1,20^{\mathrm{b}}$ & $16,29^{\mathrm{c}}$ & $14,25^{\mathrm{c}}$ & $0,71^{\mathrm{c}}$ & $0,82^{c}$ & $12,6^{\mathrm{b}}$ & $12,5^{\mathrm{c}}$ & $6,10^{\mathrm{b}}$ & $\begin{array}{c}6,40 \\
\mathrm{~b}\end{array}$ \\
\hline BNJ 5\% & 0,08 & 0,07 & 1,31 & 1,99 & 0,01 & 0,03 & 0,4 & 0,3 & 0,09 & 0,09 \\
\hline \multicolumn{11}{|l|}{$100 \mathrm{HST}$} \\
\hline $\mathrm{D}_{0}$ & $1,33^{\mathrm{d}}$ & $1,23^{\mathrm{d}}$ & $\underset{\mathrm{d}}{17,43}$ & $\begin{array}{c}10,15 \\
\mathrm{~d}\end{array}$ & $0,72^{\mathrm{d}}$ & $0,75^{b}$ & $12,7^{\mathrm{d}}$ & $\underset{\mathrm{bc}}{12,73}$ & $6,30^{\mathrm{b}}$ & $\underset{\mathrm{d}}{6,40}$ \\
\hline$D_{1}$ & $1,69^{\mathrm{b}}$ & $1,38^{b}$ & $\begin{array}{c}29,51 \\
\mathrm{~b}\end{array}$ & $\underset{\mathrm{b}}{21,58}$ & $0,79^{b}$ & $0,84^{\mathrm{b}}$ & $14,2^{\mathrm{a}}$ & $13,05^{\mathrm{b}}$ & $6,40^{\mathrm{a}}$ & $\underset{c}{6,50}$ \\
\hline $\mathrm{D}_{2}$ & $1,86^{\mathrm{a}}$ & $1,48^{\mathrm{a}}$ & $\begin{array}{c}36,56 \\
a\end{array}$ & $\begin{array}{c}29,99 \\
a\end{array}$ & $0,85^{\mathrm{a}}$ & $0,98^{\mathrm{a}}$ & $14,2^{\mathrm{a}}$ & $\underset{\mathrm{a}}{13,74}$ & $6,40^{\mathrm{a}}$ & $\underset{\mathrm{a}}{6,90}$ \\
\hline $\mathrm{D}_{3}$ & $1,47^{\mathrm{c}}$ & $1,31^{\mathrm{c}}$ & $\begin{array}{c}19,37 \\
\mathrm{c}\end{array}$ & $\underset{c}{18,59}$ & $0,75^{\mathrm{c}}$ & $0,61^{\mathrm{c}}$ & $13,1^{\mathrm{b}}$ & $11,87^{\mathrm{d}}$ & $6,30^{\mathrm{b}}$ & $\begin{array}{c}6,70 \\
\mathrm{~b}\end{array}$ \\
\hline $\mathrm{D}_{4}$ & $1,42^{\mathrm{c}}$ & $1,31^{\mathrm{c}}$ & $\underset{c}{18,53}$ & $\underset{\mathrm{c}}{17,32}$ & $0,74^{\mathrm{c}}$ & $0,60^{\mathrm{c}}$ & $12,9^{\mathrm{c}}$ & $11.81^{\mathrm{d}}$ & $6,30^{\mathrm{b}}$ & $\underset{\mathrm{b}}{6,70}$ \\
\hline BNJ 5\% & 0,08 & 0,06 & 1,0 & 2,98 & 0,01 & 0,09 & 0,19 & 0,68 & 0,09 & 0,09 \\
\hline $\begin{array}{l}\text { Awal } \\
\text { tanam }^{1)}\end{array}$ & 1,20 & - & 12,28 & - & 0,60 & - & 12,00 & - & 6,10 & - \\
\hline eterangan: & $\begin{array}{l}\text { Angk } \\
5 \% \text {; } \\
\text { mend } \\
\text { riza, }\end{array}$ & $\begin{array}{l}\text { S diik } \\
\text { lan } 2 \\
\text { puk }\end{array}$ & $\begin{array}{l}\text { huruf } \\
\text { iklus } \\
\text { rgani } \\
\text { puk }\end{array}$ & sal & am & $\begin{array}{l}\text { ya } \\
\text { klus } \\
\text { uk }\end{array}$ & la tid & $\begin{array}{l}\text { erbed } \\
\text { a); } \\
\text {; ton } \\
\text { koriza }\end{array}$ & $\begin{array}{r}\text { ata } \mathrm{m} \\
100 \\
\text { uk k }\end{array}$ & $\begin{array}{l}\text { ut uji } \\
\text { karan } \\
\text { ng + } \\
\text { upuk }\end{array}$ \\
\hline
\end{tabular}

\section{Respon pola tanam jagung - sorgum terhadap serapan hara tanaman}

Selain meningkatkan status hara tanah, perlakuan paket pemupukan $60 \%$ dari dosis pupuk rekomendasi dengan pemberian pupuk kandang 12 ton per ha serta diinokulasi dengan mikoriza $\left(D_{2}\right)$ juga dapat membantu meningkatkan serapan hara tanaman dibandingkan dengan kontrol $\left(\mathrm{D}_{0}\right)$. Hal ini nampak pada respon tanaman jagung pada siklus tanam pertama dan tanaman sorgum pada siklus tanam kedua pengamatan 60 hst yang secara nyata memberikan kontribusi terhadap peningkatan serapan N, P, K dan Ca tanaman (Tabel 2). Pada tanaman jagung meningkatkan secara nyata rata-rata serapan hara $\mathrm{N}, \mathrm{P}, \mathrm{K}$ dan Ca berturut-turut sebesar $50,37 \%, 59,06 \%, 31,45 \%$ dan $450,98 \%$ bila dibandingkan dengan kontrol $\left(\mathrm{D}_{0}\right)$. Pada tanaman sorgum meningkat secara nyata rata-rata serapan hara N, P, K dan Ca berturut-turut sebesar $63,73 \%, 127,69 \%, 39,01 \%$ dan 58,27\% bila dibandingkan dengan kontrol $\left(\mathrm{D}_{0}\right)$. 
Tabel 2. Respon pola tanam jagung - sorgum terhadap serapan hara tanaman (N, P, K dan $\mathrm{Ca})$ pada pertumbuhan vegetatif pada beberapa aplikasi paket pemupukan di lahan kering

\begin{tabular}{|c|c|c|c|c|c|c|c|c|}
\hline \multirow[t]{3}{*}{ Pemupukan** } & \multicolumn{8}{|c|}{$\begin{array}{c}\text { Serapan hara (mg/g } \\
\text { tanaman) }\end{array}$} \\
\hline & \multicolumn{4}{|c|}{ Siklus 1 jagung } & & \multicolumn{3}{|c|}{ Siklus 2 sorg } \\
\hline & $\mathrm{N}$ & $\mathrm{P}$ & $\mathrm{K}$ & $\mathrm{Ca}$ & $\mathrm{N}$ & $\mathrm{P}$ & $\mathrm{K}$ & $\mathrm{Ca}^{*}$ \\
\hline \multicolumn{9}{|l|}{$60 \mathrm{HST}$} \\
\hline $\mathrm{D}_{0}$ & $18,62^{\mathrm{e}}$ & $1,71^{\mathrm{d}}$ & $24,80^{\mathrm{e}}$ & $0,51^{\mathrm{e}}$ & $12,74^{\mathrm{d}}$ & $0,65^{\mathrm{d}}$ & $26,40^{d}$ & $4,41^{\mathrm{d}}$ \\
\hline $\mathrm{D}_{1}$ & $27,58^{\mathrm{b}}$ & $2,60^{\mathrm{b}}$ & $31,50^{\mathrm{b}}$ & $1,63^{\mathrm{b}}$ & $18,92^{\mathrm{b}}$ & $0,85^{\mathrm{c}}$ & $34,30^{\mathrm{b}}$ & $6,62^{b}$ \\
\hline $\mathrm{D}_{2}$ & $28,00^{\mathrm{a}}$ & $2,72^{\mathrm{a}}$ & $32,60^{\mathrm{a}}$ & $2,81^{\mathrm{a}}$ & $20,86^{\mathrm{a}}$ & $1,48^{\mathrm{a}}$ & $36,70^{\mathrm{a}}$ & $6,98^{\mathrm{a}}$ \\
\hline $\mathrm{D}_{3}$ & $23,10^{\mathrm{c}}$ & $2,41^{\mathrm{c}}$ & $30,50^{c}$ & $1,33^{\mathrm{c}}$ & $17,29^{\mathrm{c}}$ & $1,36^{b}$ & $29,40^{c}$ & $6,19^{c}$ \\
\hline $\mathrm{D}_{4}$ & $20,44^{\mathrm{d}}$ & $2,41^{\mathrm{c}}$ & $29,30^{\mathrm{d}}$ & $0,80^{\mathrm{d}}$ & $17,22^{\mathrm{c}}$ & $1,32^{\mathrm{b}}$ & $29,20^{\mathrm{c}}$ & $6,15^{c}$ \\
\hline BNJ 5\% & 0.41 & 0,11 & 0,9 & 0,28 & 0.07 & 0.04 & 0,20 & 0.04 \\
\hline
\end{tabular}

Keterangan: * Angka yang diikuti huruf yang sama dalam kolom yang sama tidak berbeda nyata menurut uji BNJ $5 \%$ ** Keterangan perlakuan lihat Tabel 1

Peningkatan serapan hara tanaman ini berkaitan dengan kemampuan mikoriza yang dapat meningkatkan jangkauan akar untuk mendapatkan air dan unsur hara di dalam tanah dengan bantuan hifa eksternal. Hifa ini mampu menjelajah melebihi daya jelajah akar tanaman dan dapat memasuki pori-pori tanah yang tidak dapat dimasuki akar tanaman sehingga penyerapan air dan unsur hara menjadi lebih baik (Drew, 2002). Penyerapan $\mathrm{N}$ oleh mikoriza berkaitan dengan aktivitas hifa eksternal mikoriza dalam menyerap ammonium $\left(\mathrm{NH} 4^{+}\right)$, nitrate (NO3-), dan asam amino melalui alat pengangkut dan pompa proton ATPase (Breuninger et al., 2004). Serapan hara P oleh mikoriza arbuskula dan transportnya sebagai P rantai pendek melalui hifa pada akar tanaman dipengaruhi oleh transfer karbon seperti heksosa dari tanaman inang kepada mikoriza melalui interface mikoriza. $\mathrm{P}$ disimpan di vakuola dalam bentuk ikatan rantai pendek dan panjang didalam hifa eksernal (Bücking dan Shachar-Hill, 2005).

Hifa eksternalnya mikoriza mampu memperluas daerah penyerapan dan menembus daerah penipisan nutrien yang terdapat di sekitar perakaran dan menyerap unsur hara dari daerah tersebut. Akar yang tidak terinfeksi MA tidak dapat menjangkaunya walaupun dengan rambut-rambut akar yang banyak. Sylvia (2005) menyatakan diameter hifa MA lebih kecil daripada akar tanaman dan hifa eksternal MA dapat mencapai 1-20 m per gram tanah. MA juga menghasilkan enzim fosfatase yang mampu mengkatalis hidrolis komplek fosfat tidak larut di dalam tanah menjadi bentuk fosfat larut yang tersedia bagi tanaman sehingga tanaman yang diinokulasi MA akan dapat menyerap $\mathrm{P}$ dari tanah dan dari pupuk sehingga penyerapan P menjadi lebih besar disbanding tanaman yang tidak diinokulasi MA (Gunawan, 1993). Selain unsur hara $P$, unsur lain yang serapannya terpengaruh oleh MA adalah $N$ dan K, hal ini sejalan dengan pernyataan Bueking (2005) yaitu MA dapat meningkatkan serapan P, N, Zn, Cu dan S sedangkan menurut Swift (2004) dan Suh (2005) bahwa MA dapat meningkatkan serapan $\mathrm{P}, \mathrm{K}, \mathrm{Ca}$ dan $\mathrm{Mg}$.

\section{Respon pola tanam jagung-sorgum terhadap pertumbuhan dan hasil tanaman}

Respon pola tanam jagung-sorgum pada perlakuan paket pemupukan $60 \%$ pupuk anorganik rekomendasi +12 ton pupuk kandang + mikoriza $\left(D_{2}\right)$ memberi respon yang nyata terhadap pertumbuhan dan hasil tanaman. Indikasi ini dapat dilihat dari parameter bobot biomassa kering akar dan tajuk tanaman tanaman jagung siklus pertama dan sorgum siklus kedua. Rata-rata peningkatan bobot biomassa kering akar dan tajuk perlakuan paket pemupukan $60 \%$ pupuk anorganik rekomendasi +12 ton pupuk kandang + mikoriza $\left(\mathrm{D}_{2}\right)$ 
tanaman jagung umur 60 hst adalah 110,57\% dan 113,35\% dan untuk tanaman sorgum adalah $310,97 \%$ dan $183,15 \%$ dibandingkan dengan kontrol $\left(\mathrm{D}_{0}\right)$. Sedangkan peningkatan bobot biomassa kering akar dan tajuk perlakuan paket pemupukan 60\% pupuk anorganik rekomendasi +12 ton pupuk kandang + mikoriza $\left(\mathrm{D}_{2}\right)$ pada tanaman jagung umur $100 \mathrm{hst}$ adalah $231,35 \%$ dan $78,60 \%$ dan untuk tanaman sorgum adalah 98,69\% dan 120,23\% dibandingkan dengan kontrol (Tabel 3). Rata-rata peningkatan bobot hasil biji dan 100 butir biji (g/tanaman) untuk tanaman jagung siklus pertama adalah $43,48 \%$ dan $25,08 \%$ dibandingkan dengan kontrol dan dan untuk tanaman sorgum siklus kedua adalah 17,46\% dan 32,23\% dibandingkan dengan control (Tabel 4). Sedangkan rata-rata peningkatan bobot berangkasan kering dan hasil kering panen untuk tanaman jagung siklus tanam pertama adalah $85,45 \%$ dan $137,50 \%$ dibandingkan dengan kontrol dan untuk tanaman sorgum siklus kedua adalah 49,69\% dan 86,27\% dibandingkan dengan control (Tabel 5).

Tabel 3. Respon pola tanam jagung - sorgum terhadap bobot biomassa kering akar dan tajuk tanaman umur 60 dan 100 hst pada beberapa aplikasi paket pemupukan di lahan kering

\begin{tabular}{|c|c|c|c|c|}
\hline \multirow[t]{2}{*}{ Pemupukan** } & \multicolumn{2}{|c|}{ Siklus 1 jagung } & $\begin{array}{c}\text { Bobot } \\
\text { biomassa } \\
\text { kering } \\
\text { (g/tanaman) }\end{array}$ & Siklus 2 sorgum \\
\hline & Akar & Tajuk & Akar & Tajuk* $^{*}$ \\
\hline \multicolumn{5}{|l|}{$60 \mathrm{HST}$} \\
\hline $\mathrm{D}_{0}$ & $8.13^{\mathrm{d}}$ & $34,15^{\mathrm{d}}$ & $0,82^{\mathrm{d}}$ & $8,31^{\mathrm{d}}$ \\
\hline $\mathrm{D}_{1}$ & $15,13^{\mathrm{b}}$ & $61.92^{\mathrm{b}}$ & $2,22^{\mathrm{b}}$ & $16,89^{\mathrm{b}}$ \\
\hline $\mathrm{D}_{2}$ & $17,12^{\mathrm{a}}$ & $72,86^{\mathrm{a}}$ & $3,37^{\mathrm{a}}$ & $23,53^{\mathrm{a}}$ \\
\hline $\mathrm{D}_{3}$ & $13.65^{\mathrm{c}}$ & $52,26^{\mathrm{c}}$ & $1,68^{\mathrm{c}}$ & $12,01^{\mathrm{c}}$ \\
\hline $\mathrm{D}_{4}$ & $13.34^{\mathrm{c}}$ & $51,29^{\mathrm{c}}$ & $1,38^{\mathrm{c}}$ & $11,81^{\mathrm{c}}$ \\
\hline BNJ 5\% & 0,31 & 0,97 & 0,3 & 0,2 \\
\hline \multicolumn{5}{|l|}{$100 \mathrm{HST}$} \\
\hline $\mathrm{D}_{0}$ & $10,43^{\mathrm{e}}$ & $62,29^{\mathrm{e}}$ & $12,30^{\mathrm{d}}$ & $47,74^{\mathrm{e}}$ \\
\hline $\mathrm{D}_{1}$ & $22,39^{b}$ & $109.03^{b}$ & $22,34^{\mathrm{b}}$ & $95,01^{\mathrm{b}}$ \\
\hline $\mathrm{D}_{2}$ & $34,56^{\mathrm{a}}$ & $111,25^{\mathrm{a}}$ & $24,44^{\mathrm{a}}$ & $105,14^{\mathrm{a}}$ \\
\hline $\mathrm{D}_{3}$ & $18,48^{\mathrm{c}}$ & $101,05^{\mathrm{c}}$ & $14,52^{\mathrm{c}}$ & $85,46^{\mathrm{c}}$ \\
\hline $\mathrm{D}_{4}$ & $15,43^{\mathrm{d}}$ & $95.87^{\mathrm{d}}$ & $14,47^{\mathrm{c}}$ & $66,06^{\mathrm{d}}$ \\
\hline BNJ 5\% & 3,04 & 2,21 & 0,05 & 9,54 \\
\hline
\end{tabular}

Keterangan: * Angka yang diikuti huruf yang sama dalam kolom yang sama tidak berbeda nyata menurut uji BNJ $5 \%$ *** Keterangan perlakuan lihat Tabel 1 .

Peningkatan pertumbuhan dan hasil ini menunjukkan bahwa pemberian mikoriza dan 12 ton per ha pupuk kandang dengan penambahan pupuk anorganik 60\% dari dosis rekomendasi $\left(\mathrm{D}_{2}\right)$ dapat meningkatkan kemampuan dan efisiensi tanaman dalam menyerap hara $\mathrm{P}$ untuk menunjang pertumbuhan dan hasil tanaman. Struktur hifa MA di dalam akar tanaman dan tanah mampu meningkatkan luas areal untuk pertukaran hara dan air antara tanaman dan inang, sehingga mempunyai potensi yang besar untuk meningkatkan serapan dan translokasi hara terutama $\mathrm{P}$ ke tanaman. Fosfor merupakan unsure penting penyusun substrat berenergi tinggi (ATP, ADP, AMP) yang berperan dalam metabolisme tanaman. Kegiatan metabolisme tanaman yang ditunjang oleh energi yang cukup dapat mengembangkan organ reproduktif secara berkelanjutan, sebagai hasil akhir adalah bobot biji yang besar dan bobot 100 biji yang meningkat. Mikoriza juga berperan sebagai pengendali 
biologis, meningkatkan ketahanan terhadap cekaman air dan memproduksi hormon dan zat pengatur tumbuh yang berfungsi untuk meningkatkan pertumbuhan dan hasil tanaman (Hildebrandt et al., 2002). Hasil penelitian ini sejalan dengan hasil penelitian Rahim (2002) yang menyatakan bahwa inokulasi MA bersamaan dengan pemupukan P dapat memberikan hasil yang lebih baik.

Tabel 4. Respon pola tanam jagung - sorgum terhadap bobot hasil biji dan 100 butir pada beberapa aplikasi paket pemupukan di lahan kering.

\begin{tabular}{|c|c|c|c|c|}
\hline \multirow[t]{2}{*}{ Pemupukan ${ }^{* *}$} & \multicolumn{4}{|c|}{$\begin{array}{c}\text { Bobot biji kering } \\
\text { (g/tanaman) }\end{array}$} \\
\hline & Biji & $100 \mathrm{Biji}$ & Biji & $100 \mathrm{Biji}^{*}$ \\
\hline $\mathrm{D}_{0}$ & $59.29^{d}$ & $22,48^{d}$ & $30,01^{\mathrm{d}}$ & $2,73^{\mathrm{d}}$ \\
\hline $\mathrm{D}_{1}$ & $81,17^{\mathrm{b}}$ & $26,94^{\mathrm{b}}$ & $32,46^{\mathrm{b}}$ & $3,01^{\mathrm{b}}$ \\
\hline $\mathrm{D}_{2}$ & $85,07^{\mathrm{a}}$ & $28,12^{\mathrm{a}}$ & $35,25^{\mathrm{a}}$ & $3,61^{\mathrm{a}}$ \\
\hline $\mathrm{D}_{3}$ & $67,24^{\mathrm{c}}$ & $25,98^{c}$ & $31,20^{\mathrm{c}}$ & $2,90^{c}$ \\
\hline $\mathrm{D}_{4}$ & $65,06^{c}$ & $24,61^{c}$ & $31,13^{\mathrm{c}}$ & $2,81^{\mathrm{cd}}$ \\
\hline BNJ 5\% & 2,18 & 1,37 & 0,07 & 0,09 \\
\hline
\end{tabular}

Fakta di atas menunjukkan bahwa penambahan pupuk (anorganik maupun organik plus mikoriza) sebagai tambahan sumber nutrisi sangat penting untuk meningkatkan pertumbuhan tanaman. Hal ini terkait erat dengan peran sumber nutrisi selain sebagai penyedia unsur-unsur hara yang dibutuhkan oleh tanaman, juga sebagai sumber energi dan hara bagi pertumbuhan hayati. Kedua hal tersebut diperlukan dalam meningkatkan pertumbuhan tanaman yang antara lain dipacu oleh adanya hormon tumbuh yang dihasilkan oleh pupuk hayati (Pattern dan Glick 2005). Wibowo (2007) melaporkan bahwa penggunaan pupuk hayati (Azotobacter, Azospirillum, Pseudomonas, Bacillus, dan Rhizobium) mampu meningkatkan kandungan hormon IAA rata-rata sebesar 73-159 \% pada tanaman caisim, jagung, dan kedelai.

Table 5. Respon pola tanam jagung - sorgum terhadap bobot berangkasan kering dan dan hasil kering panen pada beberapa aplikasi paket pemupukan di lahan kering.

\begin{tabular}{cccccc}
\hline \multirow{2}{*}{ Pemupukan $^{* * *}$} & \multicolumn{2}{c}{ Siklus 1 jagung } & \multicolumn{2}{c}{ Berangkasan dan hasil (kg/petak) } & Siklus 2 sorgum \\
\cline { 2 - 3 } \cline { 5 - 6 } \cline { 5 - 6 } & Berangkasan & Hasil & & Berangkasan & Hasil $^{*}$ \\
\hline $\mathrm{D}_{0}$ & $25,98^{\mathrm{e}}$ & $9,60^{\mathrm{e}}$ & & $9,80^{\mathrm{d}}$ & $3,57^{\mathrm{d}}$ \\
$\mathrm{D}_{1}$ & $42,88^{\mathrm{b}}$ & $17,40^{\mathrm{b}}$ & & $12,75^{\mathrm{b}}$ & $5,05^{\mathrm{b}}$ \\
$\mathrm{D}_{2}$ & $48,18^{\mathrm{a}}$ & $22,80^{\mathrm{a}}$ & & $14,67^{\mathrm{a}}$ & $6,65^{\mathrm{a}}$ \\
$\mathrm{D}_{3}$ & $37,80^{\mathrm{c}}$ & $15,60^{\mathrm{c}}$ & & $10,75^{\mathrm{c}}$ & $4,43^{\mathrm{c}}$ \\
$\mathrm{D}_{4}$ & $35,16^{\mathrm{d}}$ & $10,20^{\mathrm{d}}$ & & $10,12^{\text {cd }}$ & $4,17^{\mathrm{c}}$ \\
\hline BNJ 5\% & 2,63 & 0,59 & & 0,63 & 0,26 \\
\hline
\end{tabular}

Keterangan: * Angka yang diikuti huruf yang sama dalam kolom yang sama tidak berbeda nyata menurut uji BNJ $5 \% ;{ }^{* *}$ Keterangan perlakuan lihat Tabel 1. 
Respon pola tanam jagung-sorgum pada perlakuan paket pemupukan $60 \%$ pupuk anorganik rekomendasi +12 ton pupuk kandang + mikoriza $\left(\mathrm{D}_{2}\right)$ jumlah spora dan infeksi akar tertinggi dan berbeda nyata pada 60 hstdan 100 hst bandingkan dengan kontrol (Tabel 6). Peningkatan jumlah spora dan infeksi pada tanaman jagung 60 hst adalah 117,35\% dan $150 \%$ serta untuk tanaman sorgum adalah $142,16 \%$ dan $131 \%$. Sedangkan peningkatan jumlah spora pada tanaman jagung dan sorgum umur 100 hst adalah $24,91 \%$ dan $37,33 \%$.

Tabel 6. Respon pola tanam jagung - sorgum terhadap aktivitas mikoriza (jumlah spora dan persentase infeksi) pada beberapa aplikasi paket pemupukan di lahan kering

\begin{tabular}{|c|c|c|c|c|}
\hline \multirow[t]{3}{*}{ Pemupukan $^{* *}$} & \multicolumn{3}{|c|}{$\begin{array}{l}\text { Spora } 100 \mathrm{~g} \mathrm{tanah}^{-1} \text { dan infeks } \\
\text { akar }\end{array}$} & \multirow{3}{*}{$\begin{array}{c}\text { Siklus } 2 \text { sorgum } \\
\text { Infeksi }^{*}\end{array}$} \\
\hline & \multicolumn{2}{|c|}{ Siklus 1 jagung } & \multirow[b]{2}{*}{ Spora } & \\
\hline & Spora & Infeksi & & \\
\hline \multicolumn{5}{|l|}{$60 \mathrm{HST}$} \\
\hline $\mathrm{D}_{0}$ & $764^{e}$ & $30^{\mathrm{d}}$ & $1231^{\varsigma}$ & $35^{\mathrm{e}}$ \\
\hline $\mathrm{D}_{1}$ & $1059^{d}$ & $55^{\mathrm{c}}$ & $1343^{c}$ & $60^{\mathrm{d}}$ \\
\hline $\mathrm{D}_{2}$ & $2119^{a}$ & $75^{\mathrm{a}}$ & $2981^{c}$ & $81^{\mathrm{a}}$ \\
\hline$D_{3}$ & $1690^{\mathrm{b}}$ & $65^{\mathrm{b}}$ & $1881^{\mathrm{t}}$ & $77^{\mathrm{b}}$ \\
\hline $\mathrm{D}_{4}$ & $1294^{c}$ & $63^{b}$ & $1769^{\prime}$ & $68^{c}$ \\
\hline BNJ 5\% & 231 & 2 & 109 & 6,5 \\
\hline \multicolumn{5}{|l|}{$100 \mathrm{HST}$} \\
\hline $\mathrm{D}_{0}$ & $3464^{d}$ & - & $3761^{c}$ & - \\
\hline $\mathrm{D}_{1}$ & $3672^{c}$ & - & $4942^{\mathrm{k}}$ & - \\
\hline $\mathrm{D}_{2}$ & $4327^{\mathrm{a}}$ & - & $5165^{i}$ & - \\
\hline $\mathrm{D}_{3}$ & $3894^{\mathrm{b}}$ & - & $4831^{\prime}$ & - \\
\hline $\mathrm{D}_{4}$ & $3881^{\mathrm{b}}$ & - & $4819^{\prime}$ & - \\
\hline BNJ 5\% & 13 & & 12 & \\
\hline Awal tanam ${ }^{1)}$ & 421 & - & - & - \\
\hline \multicolumn{5}{|c|}{$\begin{array}{l}\text { Keterangan: * Angka yang diikuti huruf yang sama dalam kolom yang sama tidak berbeda nyata menurut uji } \\
\text { BNJ 5\%; }{ }^{* *} \text { Keterangan perlakuan lihat Tabel } 1\end{array}$} \\
\hline \multicolumn{5}{|c|}{$\begin{array}{l}\text { Menurut Wilson dan Trinick (1983), kemampuan MA memproduksi spora } \\
\text { menunjukkan efektivitas simbiosis MA pada perakaran tanaman. Menurut Alloush et al. } \\
\text { (2000) penambahan pupuk selain mengurangi infeksi juga akan mengurangi manfaat MA. } \\
\text { Unsur P tersedia cukup tinggi dapat menyebabkan penurunan jumlah eksudat akar (Graham } \\
\text { et al., 1981), perubahan kualitas eksudat (Elias and Safir, 1987), penurunan permeabilitas } \\
\text { membran (Ratanayke et al., } 1978 \text { dalam Fries et al., 1998), dan peningkatan aktivitas } \\
\text { peroksidase yang dapat menyebabkan lignifikasi dinding sel akar serta menghambat } \\
\text { pertumbuhan intraradical cendawan. Akibatnya, infeksi MA pada akar menurun (Fries et al., } \\
\text { 1998). }\end{array}$} \\
\hline
\end{tabular}

\section{KESIMPULAN}

Hasil penelitian menunjukkan bahwa respon pola tanam jagung - sorgum pada paket pemupukan $60 \%$ lebih rendah dari dosis pupuk rekomendasi dengan penambahan pupuk kandang 12 ton per ha disertai dengan inokulasi mikoriza meningkatkan kesuburan tanah yang tercermin dengan meningkatkan status hara $\mathrm{N}, \mathrm{P}, \mathrm{K}$ dan kandungan bahan organik tanah, meningkatkan serapan hara tanaman $(\mathrm{N}, \mathrm{P}, \mathrm{K}$ dan $\mathrm{Ca})$, pertumbuhan, hasil tanaman dan aktivitas MA di dalam tanah 


\section{DAFTAR PUSTAKA}

Alloush, G.A.Z., S.K. Zeto, R.B. Clark. 2000. Phosphorus source, organic matter, and arbuscular mycorrhiza effects on growth and mineral acquisition of Chikpea grown in acidic soils. J. Plant Nutrition. 23(9): 1351-1369.

Astiko W, IR Sastrahidayat, S Djauhari dan A Muhibuddin. 2013. The role of indigenous mycorrhiza in combination with cattle manure in improving maize yield (Zea mays L.) on sandy loam of Norhern Lombok, Eastern of Indonesia. Journal of Tropical Soils. 18 (1): 53-58

Astiko, W., I.R. Sastrahidayat, S. Djauhari dan A. Muhibuddin. 2013a. Soil fertility status and soybean [Glycine $\max (\mathrm{L})$ Merr] performence foloowing introduction of indigenous mycorrhiza combined with various nutrient sources into sandy soil. Agrivita. 35 (2): $127-137$

Astiko, W. 2013b. The Role of Indigenous Mycorrhizae in Different Plant Patterns to Increase Soybean Yield in Sandy Soil (Case Studies on Dryland North Lombok). Dissertation. Post Graduate Program of Universitas Brawijaya, Malang

Astiko W, MT Fauzi dan Sukartono. 2015. Nutrient status and mycorrhizal population on various food crops grown following corn inoculated with indigenous mycorrhiza on sandy soil of North Lombok, Indonesia. Journal of Tropical Soils. 20 (2): 119-125

Brundrett M, N Bougher, B Dell, T Grove dan N Malajczulk. 1996. Working with Mycorrhizas in Forestry and Agriculture. The Australian Centre for International Agriculture Research (ACIAR) Monograph 32. pp. 374

Breuninger, M., C.G. Trujillo, E. Serrano, R. Fischer, N. Requena. 2004. Different nitrogen sources modulate activity but not expression of glutamine synthetase in arbuscular mycorrhizal fungi. Fung. Gen. and Biol. 41: 542-552.

Bueking, H. 2005. Rutgers The State University of new Jersey http:/crab.rutgers.edu/bucking/jobs.htm [10 Juli 2010].

Bücking, H., Y. Shachar-Hill. 2005: Phosphate uptake, transport and transfer by Glomus intraradices is stimulated by increased the arbuscular mycorrhizal fungus carbohydrate availability. New Phytol. 165: 899-912.

Cruz, C., J.J. Green, C.A. Watson, F. Wilson, M.A. Martin-Lucao. 2004. Functional aspects of root architecture and mycorrhizal inoculation with respect to nutrient uptake capacity. Mycorrhiza 14: 177-184

Daniels BA dan H.D. Skipper. 1982. Methods for recovery and quantitative estimation of propagules from soil. In N.C. Scenck (Eds.). Methods and principle of mycorrhiza research. APS, St. Paul MN. p. 29-36

Drew EA. 2002. External AM hyhae: their growth and function in media of varying pore sizes. PhD thesis. Departement of Soil and Water, The University of Adelaide, Adelaide, Australia

Elias, K.S., G.R. Safir. 1987. Hypal elongation of Glomus fasciculatus in response to root exudates. Appl. Environ. Microbiol. 53:1928-1933.

Fries, L.L.M., R.S. Pacovsky, G.R. Safir. 1998. Influence of phosphorus and formononetin in isozyme expression in the Zea mays-Glomus intraradices symbiosis. Physiologia Plantarum. 103: 172-180.

Giovannetti M dan B Mosse. 1980. An evaluation of techniques to measure vesiculararbuscular mycorrhiza infection in roots. New Phytol. 84: 489-500.

Gunawan, A.W. 1993. Mikoriza arbuskula. Pusat Antar Universitas (PAU) Ilmu Hayat. Institut Pertanian Bogor

Graham, J.H., R.T. Leonard, J.A. Menge. 1981. Membrane-mediated decrease in root exudation responsible for phosphorus inhibition of vesiculararbuscular mycorrhiza formation. Plant Physiol. 63: 548-552. 
Hildebrandt, U., K. Janetta, H. Bothe. 2002. Towards growth of arbuscular mycorrhizal fungi independent of a plant host. Appl. Environ. Microbiol. 68:1919-1924.

Kormanik PP dan AC McGraw. 1982. Quantification of vesicular-arbuscular mycorrhiza in plant roots. In N.C. Scenk (Eds). Methods and principles of mycorrhizal research. The American Phytopathologycal Society. St. Paul. Minnesota. pp. 244

Pattern CL, Glick BR. 2002. Role of Pseudomonas putida indole acetic acid in development of the the plant root system. Appl Environ Microbiol 68: 3795 - 3801

Rahim, K.A. 2002. Biofertilizer in Malaysian Agriculture: Perception, demand and promotion. FNCA Joint Workshop on Mutation Breeding and Biofertilizer, August 2023. Beijing, China.

Rifan, J., Maryanto, Karisun. 2002. Upaya pemanfaatan mikoriza, gambut dan BFA terasidulasi sebagai bahan amelioran untuk meningkatkan produktivitas kedele di tanah liat aktivitas rendah (LAR). Laporan Penelitian. Fakultas Pertanian, Universitas Jenderal Soedirman, Purwokerto.

Smith SE, E Facelli, S Pope dan F A Smith. 2010. Plant performance in stressful environments: interpreting new and established knowledge of the roles of arbuscular mycorrhizas. Plant soil. 326: 3-20

Supardi G. 1996. Mining the Synergistic Effects towards Strong Agriculture. HITI News. 4 (12): 10-13.

Suh, J.S. 2005.Application ofVAmycorrhizae and phosphate solubilizers as biofertilizers in Korea. FNCA Joint Workshop on Mutation Breeding and Biofertilizer. China 20-23 August 2002.

Swift, C.E. 2004. Mycorrhiza and soil phosphorus levels. http://www.colostate.edu/Depts/CoopEkt/TRa/ PLANT/mycorrhiza.html $\quad\left[\begin{array}{ll}10 & \text { Juli }\end{array}\right.$ 2010].

Sylvia, D.M. 2005. Mycorrhizal symbioses. p. 263-282. In Principle and Applications of Soil Microbiology. New Jersey: 2 nd Edition. Pearson Prentice Hall, Upper Saddle River.

Wangiyana W, PS Cornish, and EC Morris. 2006. Arbuscular mycorrhizal fungi (AMF) dynamics in contrasting cropping systems on vertisol and regosol soils of Lombok, Indonesia. Experimental Agriculture, 42: 427-439 (October, 2006). DOI:10.1017/S0014479706003826

Wilson, J.M., M.J. Trinick. 1983. Infection development and interaction between vesicular arbuscular mycorrhizal fungi. New Phytol. 95:543 -553.

Wibowo ST. 2007. Kandungan hormon IAA, serapan hara, dan pertumbuhan beberapa tanaman budidaya sebagai respon terhadap aplikasi pupuk biologi. Tesis. Program Pasca Sarjana IPB. Bogor. 